\title{
A Simple Method to Estimate Spatial Complexity in Aquatic Plants
}

\author{
Eric David Dibble ${ }^{1 *}$ and Sidinei Magela Thomaz ${ }^{2}$ \\ ${ }^{I}$ Department of Wildlife and Fisheries; Mississippi State University; edibble@cfr.msstate.edu; MS 39762; \\ Mississippi - USA. ${ }^{2}$ Departamento de Biologia; Programa de Pós-Graduação em Ecologia de Ambientes Aquáticos \\ Continentais; Nupelia; Universidade Estadual de Maringá; Av. Colombo, 5790; smthomaz@nupelia.uem.br; \\ 87020-900; Maringá - PR - Brasil
}

\begin{abstract}
We used a computerized approach to measure spatial complexity for the structural habitat provided by eight aquatic plant species collected from backwater lagoons located in the Upper Parana River floodplain, Brazil. The plant species were: Cabomba furcata Schult. and Schult.f., Eichhornia azurea (Sw.) Kunth (stems and roots), Eichhornia crassipes (Mart.) Solms, Egeria najas Planchon, Heteranthera $c f$. zosterifolia, Potamogeton $c f$ pusillus, Utricularia foliosa $L$., and Nymphaea amazonum Mart. and Zucc. The upper $0.5 \mathrm{~m}$ length of the terminal stems was quantified for complexity. Mean frequency and length of the interstices were significantly different among plant species. Spatial complexity varied $(F=17.30 ; p<0.0001)$ among the different plant species with $\mathrm{E}$. azurea roots and $\mathrm{U}$. foliosa exhibiting the highest levels and $\mathrm{E}$. azurea and $\mathrm{N}$. amazonum stems the lowest. These unique spatial complexities suggested that aquatic plants possessed a differential contribution to the habitat heterogeneity in Upper Paraná River lagoons.
\end{abstract}

Key words: Aquatic plant structure, spatial complexity, architecture, habitat heterogeneity.

\section{INTRODUCTION}

Aquatic plant morphologies provide important habitat heterogeneity in aquatic systems, and the spatial structure unique to plants is important to the growth and survival of many freshwater organisms. Previous studies have suggested that spatial complexity innate to the structural architecture of an individual plant creates diverse habitat important to macroinvertebrates and fishes (Lille and Budd, 1992; Dibble et al., 1996a; Taniguchi et al., 2003). The spatial complexity created by plant stems and leaves provide a substrate for the attachment of macroinvertebrates and as a result promotes a rich forage base for fishes (Gilinksky, 1984; Keast, 1984). Interstices among leaves and stems are important to early life stages of fishes as refuge from predators and as nursery areas (Floyd et al., 1984; Ferrer-Montano and Dibble, 2002). The level of spatial complexity available in vegetated habitats can determine trophic interactions among fishes and their prey by mediating foraging efficiencies (Diehl, 1988; Dibble and Harrel, 1997; Harrel and Dibble, 2001).

Understanding how aquatic plants differentially influence the structural component of freshwater habitats is especially important to appropriate management of littoral zones of reservoirs and backwater lagoons in rivers, where restoration and

\footnotetext{
${ }^{*}$ Author for correspondence
} 
or control programs are implemented. However, the management of aquatic plants in these freshwater systems is frequently determined by habitat measurements at an inappropriate scale. Vegetated habitats are typically quantified and characterized at a scale not relevant to the requirements of fresh water inhabitants, i.e. fishes and macroinvertebrates, and characterized as abundance or standing crop (Maceina et al., 1984; Duarte, 1987). A few field ecologists in North America have attempted to quantify the structural complexity in aquatic plants that provide heterogeneity important to habitat (Lillie and Budd, 1992; Dibble et al., 1996b). Recent studies in Brazil also have addressed aquatic plant complexity but have used leaf-area based indices (Henry and Costa, 2003) or measured canopy layer structure employing a semi-quantitative scoring system (Murphy et al., 2003). Delineating morphological differences in aquatic plants and quantifying innate complexity at this scale is an essential step in characterizing and understanding their unique ecological importance and differential function of vegetated habitats in aquatic systems. Aquatic vegetation, both submerged and floatingleaved, are considered key factors in maintaining high invertebrate (Lansac-Tôha et al., 2003; Takeda et al., 2003) and fish (Agostinho et al., 2003; Pelicice et al., 2005) diversity in the Upper Paraná River floodplain habitats in Brazil. Recent investigations have clearly shown a significant increase in fish diversity and a decrease in fish size in the border of the floating-emergent plant Eichhornia azurea (Baltar et al., in press) and inside stands of the submerged Egeria densa and E. najas (Pelicice et al., 2005). Nevertheless, to our knowledge, no characterization of plants at this scale has been provided for aquatic macrophytes in Brazilian waterbodies.

The objective in this work was to use a new method to quantify differences in architectural complexity of eight macrophyte species native to the Upper Paraná River basin at a scale potentially important to freshwater organisms.

\section{MATERIAL AND METHODS}

\section{Plant collections}

Eight aquatic plant species were collected in September of 2003 from backwater areas in two lagoons located near Porto Rico Island in the Upper Paraná River: the submerged Cabomba furcata, Egeria najas, Heteranthera cf. zosterifolia, Potamogeton cf pusillus and Utricularia foliosa; the rooted-stem floating and emergent leaves Eichhornia azurea; the freefloating Eichhornia crassipes, and the rooted with floating leaves Nymphaea amazonum. Three replicates for each plant species were collected from a boat by hand and using an anchor drag rake. Plant samples were taken from the edge of dense plant beds or from isolated plants growing individually so as to reduce density effect on growth form. This insured that all plant specimens contained maximized stem and leaf development for our analysis. All plant specimens (except $E$. najas) represented mature flowering plants, and all samples (except $E$. crassipes) contained the upper $(0.5 \mathrm{~m})$ portion of the plant, including the apical stem(s) and leaves. A sample was taken of the suspended root mass of E. crassipes, which similarly occupied the upper strata of the water column. For E. azurea, stems and roots were analyzed separately since both served as substrate for fish and invertebrate. The upper portion of structural habitat (roots or stems) provided by the plant was selected as a sample because it represented the most viable area within the water column potentially utilized by aquatic fauna (i.e., fish and macroinvertebrates). The upper stratum of the water column in vegetated habitat typically contains relatively higher levels of dissolved oxygen and light (Jones et al., 1996; Miranda et al., 2000). Each specimen was carefully removed from the water column and placed in plastic bags containing water and immediately transported to the laboratory for further analysis.

\section{Complexity and architectural measurements}

Each plant specimen was placed on a light table, its leaves and stem(s) carefully positioned to emulate a natural submerged condition on a bidimensional plan, and a digital photo was made. Powerpoint software (Microsoft, Version 5.1) was used to superimpose a line transect and measuring grid onto the digital image of the plant specimen (Fig. 1).

Each digital image was analyzed using vertical and horizontal axes of the line transect and grid. One vertical and one horizontal transect was overlaid randomly within the vegetative borders of the plant image. Interstices (open space between stems and leaves) were counted and measured along each transect starting with the first vegetative material (leaf or stem) intersected and ending with the last 
vegetative material intercepted. Interstice frequency $(f)$ and length $(l)$ along both transected axes were determined to calculate spatial complexity $\left(I_{h v}\right)$ for each plant. The index for complexity $\left(I_{h v}\right)$ was calculated as $f_{h} / l_{h}+f_{v} / l_{v}$ (after Dibble et al. 1996a). Where: $f_{h}=$ mean frequency or number of interstices intercepted per meter along a horizontal axis; $l_{h}=$ mean length $(\mathrm{cm})$ of interstices along a horizontal axis; $f_{v}=$ mean frequency or number of interstices intercepted per meter along a vertical axis; $l_{v}=$ mean length $(\mathrm{cm})$ of interstices along a vertical axis. Higher values of the complexity index $I_{h v}$, reflect higher frequencies and smaller lengths of interstices between the individual stems, roots and leaves of a plant. The routine "Standard tests" and the test of ANOVA - Monte-Carlo of ECOSIM, version 7.22 (Gotelli and Entsminger, 2001) were used to test for significant differences among $f_{h}, l_{h}, f_{v}, l_{v}$. and $I_{h v}$. A linear regression was used to investigate the relationship in lengths and frequencies of interstices among the plant species.

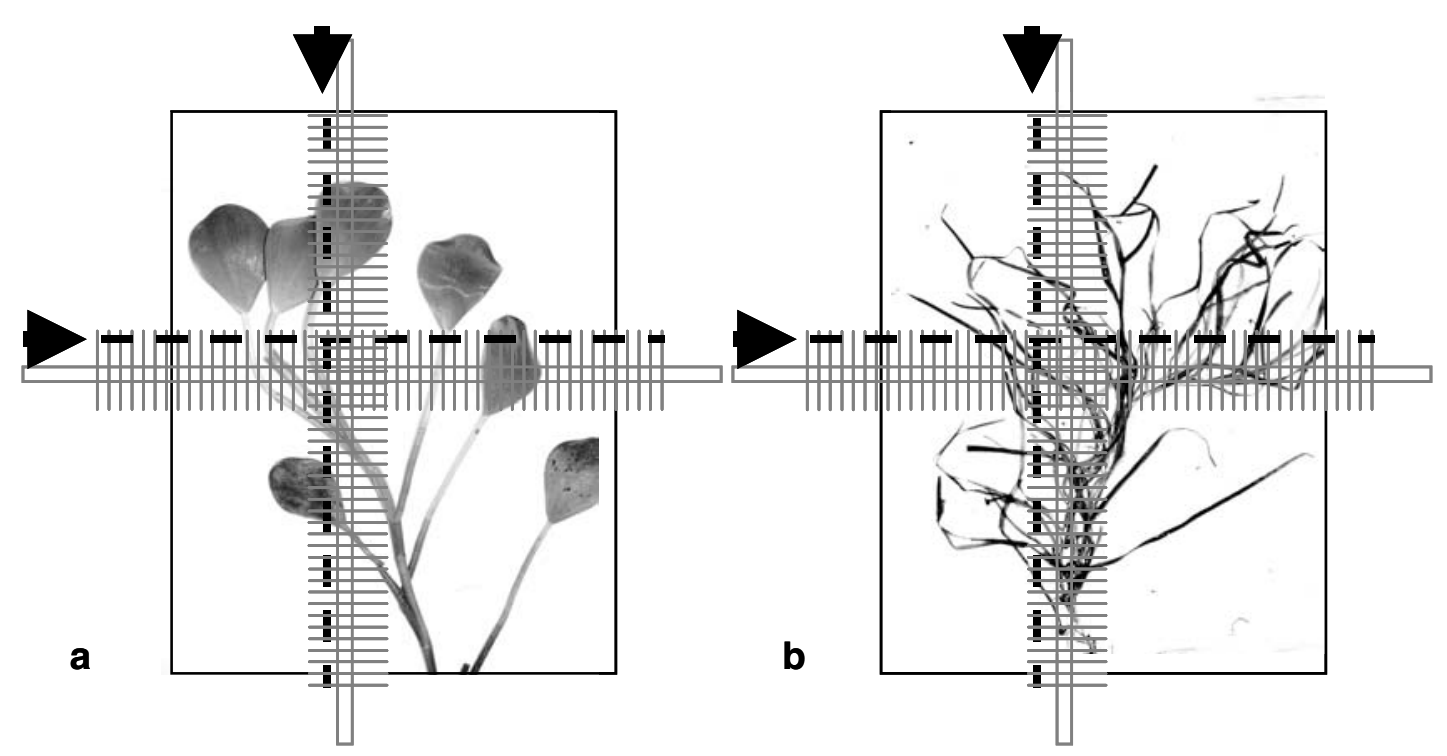

Figure 1 - Example of the digital images of two plant specimens: Eichhornia azurea (a) and Heteranthera cf. zosterifolia (b) with the superimposed overlay of vertical and horizontal sampling transects (dashed line) and rule $(\mathrm{cm})$ used to determine the frequency $\left(f_{h v}\right)$ and size $\left(l_{h v}\right)$ of plant interstices.

\section{RESULTS}

All measurements targeted plant structure typically found growing underwater and thus represented subsurface morphology typically exhibited by the different plant species. Mean vertical lengths $(F=$ $18.60 ; \mathrm{p}<0.0001)$, vertical frequencies $(F=$ 24.88; $<<0.0001)$, horizontal lengths $(F=8.33 ; \mathrm{p}$ $<0.001)$ and horizontal frequencies $(F=7.61 ; \mathrm{p}<$ 0.0001 ) of the interstices differed significantly among the plant species (Table 1). All of the aquatic plants, except $E$. najas, exhibited a higher number of interstices along the horizontal rather than the vertical axis (Table 1; Fig 2a). The frequency along both horizontal and vertical interstices were highest in $C$. furcata, E. crassipes, Heteranthera cf. zosterifolia, Potamogeton cf pusillus and U. foliosa, whereas, N. amazonum, and E. azurea stems contained the lowest frequency of interstices. E. najas had dissimilar frequencies along the two axes, whereas $C$. furcata and E. azurea stems were similar, in that they exhibited the most equal frequency and number of interstices along both axes (Table 1; Fig 2a). E. 
azurea roots had higher frequencies of both horizontal and vertical interstices but the number of horizontal were higher than vertical ones (Table 1; Fig 2a).

The lengths of interstices measured along both axes were similar in all plants, except in E. najas and $N$. amazonum (Table 1; Fig 2b). Mean length of horizontal and vertical interstices across all plants ranged from $1.5-7.0$ and $1.4-17.7 \mathrm{~cm}$, respectively. The shortest interstices were recorded in the vertical axis of E. najas, and horizontal axis of $U$. foliosa. Interstitial length recorded along the horizontal axis of E. najas was 5 times higher than the mean interstitial length along its vertical axis (Table 1; Fig 2b). On the other hand, interstitial length recorded along the vertical axis of $N$. amazonum was two times higher than the mean length of interstices found horizontally, and the vertical interstice length was at least three times greater than all of the other plants (Table 1; Fig 2b).

Spatial complexity values $\left(I_{h v}\right)$ ranged from 3.0 to 84.3 and significantly varied $(F=17.30 ; \mathrm{p}<$ 0.0001 ) among the nine samples we measured (Fig 3 ). Because of its longer vertical interstices, $N$. amazonum exhibited the lowest mean complexity $(3.0, \mathrm{SD}=1.4)$, and mean complexity for the submersed roots of E. azurea $(84.6, \mathrm{SD}=11.9)$ was the highest. $U$. foliosa also exhibited a high mean complexity $(58.4, \mathrm{SD}=13.3)$ because of its high frequency of small sized interstices within its stem and leave morphology. P. pusillus, $H$. cf. zosterifolia, C. furcata, E. najas and E. crassipes roots contained relatively intermediate mean complexity levels. Differently from its roots, mean spatial complexity for $E$. azurea stems was very low $(5.7, \mathrm{SD}=1.8)($ Fig 3$)$.

Table 1 - Differences in mean interstice frequency $(f)$ and length $(l)$ along horizontal and vertical axes measured among eight species of aquatic plants collected from lagoons in the Paraná River, Brazil. SD are values represented in the parentheses.

\begin{tabular}{|c|c|c|}
\hline \multirow[b]{2}{*}{ Plant species } & \multicolumn{2}{|c|}{ Plant Interstices } \\
\hline & Frequency (no./m) & Length (cm) \\
\hline & \multicolumn{2}{|c|}{ (Horizontal) } \\
\hline Cabomba furcata & $35.0(9.0)$ & $2.2(1.0)$ \\
\hline Egeria najas & $22.5(15.6)$ & $7.0(2.1)$ \\
\hline Eichhornia azurea - stems & $13.3(1.4)$ & $4.2(1.7)$ \\
\hline Eichhornia azurea - roots & $81.7(2.9)$ & $1.6(0.7)$ \\
\hline Eichhornia crassipes - roots & $40.8(2.9)$ & $1.8(0.1)$ \\
\hline Heteranthera cf. Zosterifolia & $37.5(4.3)$ & $2.0(0.3)$ \\
\hline Nymphaea aтаzопит & $15.0(4.3)$ & $6.3(2.3)$ \\
\hline Potamogeton cf. pusillus & $32.5(3.0)$ & $3.0(0.7)$ \\
\hline \multirow[t]{2}{*}{ Utricularia foliosa } & $50.0(8.7)$ & $1.5(0.5)$ \\
\hline & \multicolumn{2}{|c|}{ (Vertical) } \\
\hline Cabomba furcata & $34.7(4.6)$ & $2.0(0.5)$ \\
\hline Egeria najas & $48.0(6.0)$ & $1.4(0.4)$ \\
\hline Eichhornia azurea - stems & $10.7(1.2)$ & $5.4(1.3)$ \\
\hline Eichhornia azurea - roots & $40.7(5.0)$ & $1.5(0.6)$ \\
\hline Eichhornia crassipes - roots & $34.0(12.0)$ & $2.6(1.1)$ \\
\hline Heteranthera cf. zosterifolia & $20.7(1.2)$ & $3.7(1.0)$ \\
\hline Nymphaea amazonum & $5.3(1.2)$ & $17.7(4.2)$ \\
\hline Potamogeton cf. pusillus & $24.7(14.0)$ & $5.1(3.9)$ \\
\hline Utricularia foliosa & $36.0(12.0)$ & $2.1(0.8)$ \\
\hline
\end{tabular}

\section{DISCUSSION}

To our knowledge this is the first attempt to quantify species specific morphology by measuring the spatial complexity in aquatic plants in South America. Earlier attempts were made using different approaches (Henry and Costa, 2003; Murphy et al., 2003). Most investigations 
relating fish and invertebrates assemblages to aquatic vegetation in Brazil assumed that the relationship was due to structural habitat provided by plants, but rarely quantified plant complexity. Instead, they considered only the plant presence or absence (Araujo-Lima et al., 1986; Baltar et al., in press; Lansac-Tôha et al., 2003; Takeda et al., 2003), plant relative abundance (Agostinho et al., 2003) or plant biomass (Vono and Barbosa, 2001; Pelicice et al., 2005).

This approach was relatively simple way of determining differences and similarities in the structural architecture of aquatic plants and the degree that a single plant species contributed to spatial heterogeneity in aquatic habitat. For example, by comparing differential number and frequency of interstices measured between horizontal and vertical axes in E. najas, C. furcata, and $N$. amazonum suggest that the first two species provided similar structural complexity available to aquatic organisms, but they differed considerably from that of the simple structure of $N$. amazonum (Fig 2). In addition, comparison in the complexity values between different plant structures suggested that they differed significantly in what structural component they provided and their contribution to the ecology of aquatic systems. For example, the spatial complexity of the habitat provided by $E$. crassipes and E. azurea roots was highly complex compared to E. azurea stems. Thus, the stem/root complex of E. azurea provided two different spatial habitats immediately below the water surface: a low complexity habitat dominated by stems, and a deeper more complex habitat where roots dominated. Such heterogeneity within these plant beds at a micro-scale could mediate colonization and the structure of fish and invertebrate assemblages.
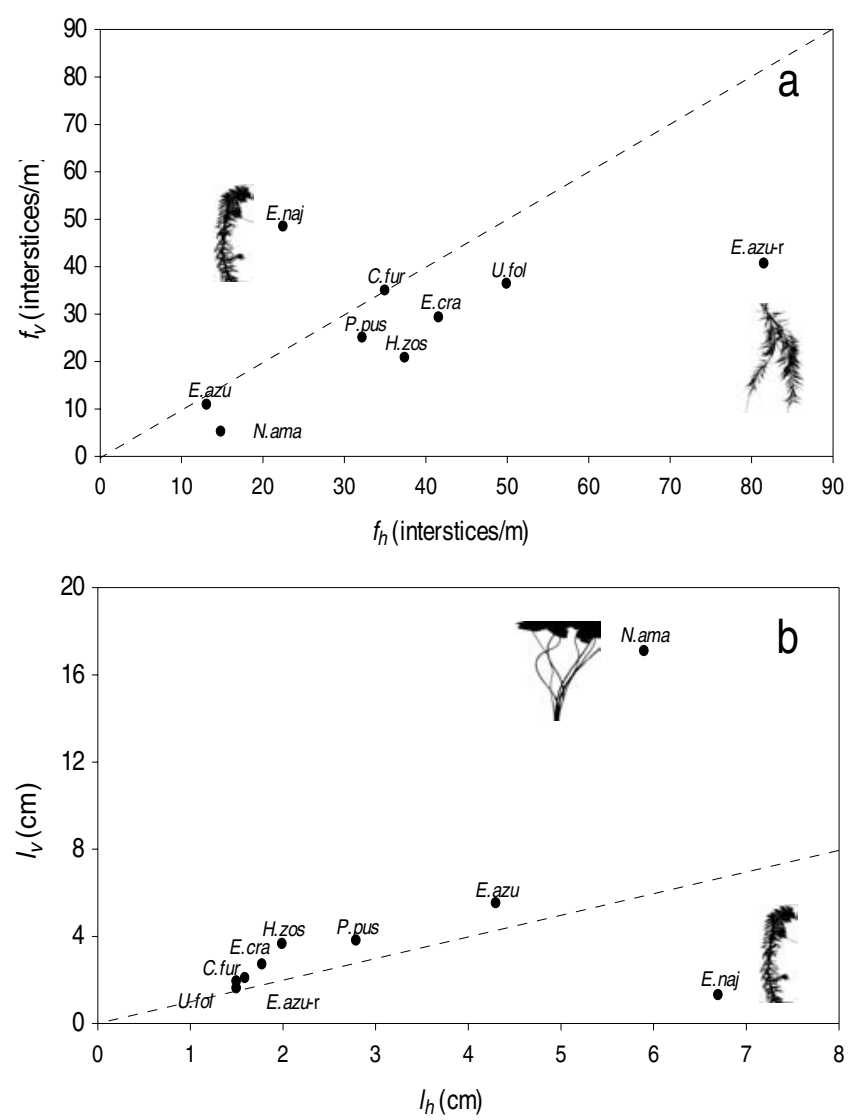

Figure 2 - Relationship between the mean frequencies of vertical $\left(f_{v}\right)$ and horizontal $\left(f_{h}\right)$ interstices (a) and between the mean lengths of the vertical $\left(l_{v}\right)$ and horizontal $\left(l_{h}\right)$ interstices (b). E.azu: Eichhornia azurea - stems; E.azu-r: Eichhornia azurea - roots; N.ama: Nymphaea amazounum; H.zos: Heteranthera cf. zosterifolia; P.pus: Potamogeton cf. pusillus; C.fur: Cabomba furcata; E.naj: Egeria najas; U.fol: Utricularia foliosa; E.cra: Eichhornia crassipes. Lines represent the 1:1 tendencies. 


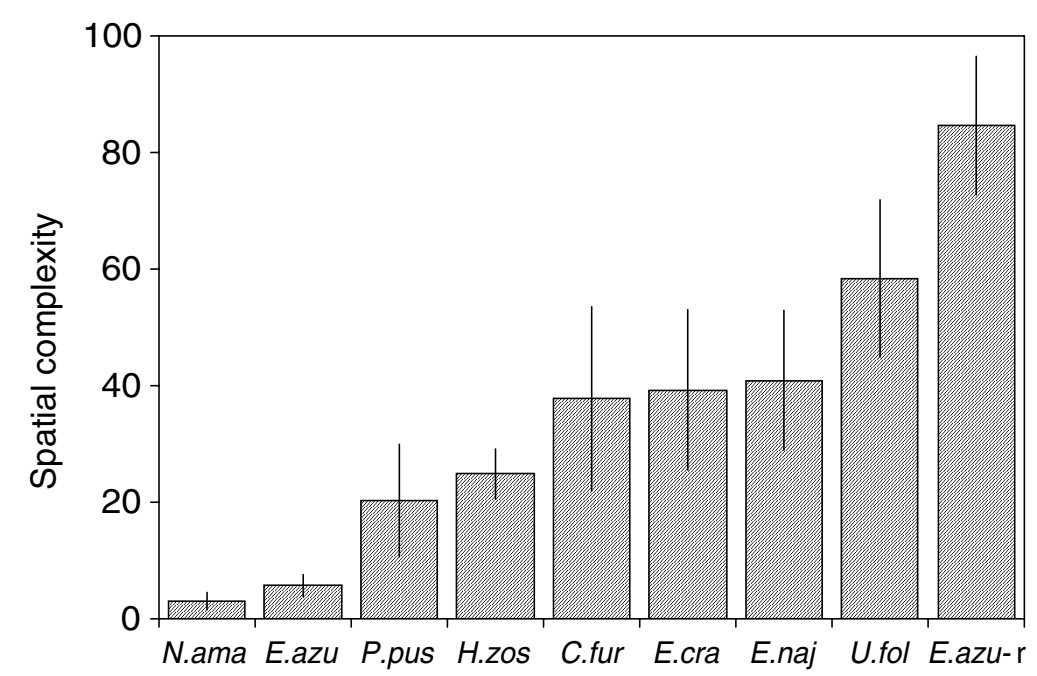

Figure 3 - Differences in calculated spatial-complexity values $\left(I_{h v}\right)$ among the eight aquatic plants samples from the Paraná Floodplain, Brazil. Lines represent standard error. Species names are the same as in Fig. 2.

No scale was considered in present measurements and the comparisons made were only valid at one scale. However, the plant complexity calculations represented an initial step to better describe habitat heterogeneity in vegetated habitats of the Upper Paraná River. The application of the complexity measurements at different scales would no doubt complement the results presented here. Hypotheses in aquatic plant ecology are only pertinent at a specific scale of measurement (Farmer and Adams, 1991), thus a hierarchical perspective must be considered since structural complexity may change at different scales within the plant. It must also be pointed out that present measurements might have been less accurate, because interstices data were recorded on a bidimensional plan. An alternative approach could be used to correct for this by measuring spatial complexity at a tri-dimensional level (e.g., in aquaria or underwater, in the field), which could improve the accuracy of measurement. In this respect, more underwater measurement needs to be pursued to quantify of plants under natural conditions. Future study is required to improve both the resolution and accuracy of interstices measurement to better quantify the structures unique to aquatic plants.

In summary, the differences in architecture suggest that each plant species has a unique contribution to the environment of backwater lagoons, and that each plant provides a different component of heterogeneity to the habitat of aquatic organisms.
Present complexity measurement could be used as a predictor of several attributes at the population (e.g., size structure, density) and community (e.g., species richness, alfa and beta diversity) levels of other organisms that used aquatic plants as refuge and feeding sites. In addition, its use as an independent variable, measuring habitat heterogeneity to explain biological diversity, may be considered important in management strategies aiming at aquatic biodiversity restoration and conservation. By relating the complexity of vegetated habitat to community structure the ability to quantify mechanisms functioning in aquatic ecosystems is refined (Weaver et al. 1996). The inclusion of complexity measurements in future studies, especially at different scales, would certainly contribute to a better understanding of how aquatic plants structure communities and mediate spatial heterogeneity within aquatic habitats.

\section{ACKNOWLEDGMENTS}

We would like to acknowledge the University of Maringá-Nupélia for field and laboratory facilities, and appreciate comments provided by Robin Dibble, André Andrian Padial, and Sandra A. Pierini. This research was partially funded by $\mathrm{CNPq}$ through a grant to S.M. Thomaz, and a grant to E.D. Dibble through USDA Research and Scientific Exchanges (Washington, DC) and by the 
Department of Wildlife and Fisheries, and the Forestry and Wildlife Research Center at Mississippi State University.

\section{RESUMO}

Neste trabalho foi medida a complexidade espacial que contribui para a estrutura de habitat proporcionada por 8 espécies de plantas aquáticas coletadas em lagoas da planície de inundação do alto rio Paraná. As espécies analisadas foram Cabomba furcata Schult. and Schult.f. Eichhornia azurea (Sw.) Kunth (caules e raízes), Eichhornia crassipes (Mart.) Solms, Egeria najas Planchon, Heteranthera cf. zosterifolia, Potamogeton cf pusillus, Utricularia foliosa L. e Nymphaea amazonum Mart. and Zucc. A complexidade dos segmentos terminais de $0,5 \mathrm{~m}$ foi medida em laboratório. Fotografias digitais desses segmentos foram feitas e análises dos eixos verticais e horizontais foram realizadas ao longo de transecções superpostas às imagens, em computador. A freqüência e o comprimento dos insterstícios ao longo de ambos os eixos foram tomados para determinar o índice de complexidade espacial. A freqüência e o comprimento médios dos interstícios foram significativamente diferentes entre as espécies de plantas. A complexidade espacial também variou entre as espécies $(F=17,30 ; \mathrm{p}<0,0001)$, com as raízes de E. azurea e $U$. foliosa exibindo os maiores valores e os caules de E. azurea e $N$. amazonum os menores. Estes valores da complexidade espacial, únicos para cada espécie, sugerem que as plantas aquáticas possuem uma contribuição diferenciada para a heterogeneidade de habitats dos ambientes aquáticos do alto rio Paraná.

\section{REFERENCES}

Agostinho, A. A.; Gomes, L. C. and Julio Jr., H. F. (2003), Relações entre macrófitas aquáticas e fauna de peixes. In-Ecologia e Manejo de Macrófitas Aquáticas, eds. S. M. Thomaz and L. M. Bini. Eduem, Maringá, pp. 261-277.

Baltar, S. L. S. M. A., Agostinho, A. A., Thomaz, S. M. and Gomes, L. C. (in press), Influence of aquatic macrophytes on fish assemblages structure of the Upper Paraná River Floodplain (Brazil). Aquat. Ecol.
Araujo-Lima, C. A. R. M.; Portugal, L. P. S. and Ferreira, E. G. (1986), Fish-macrophyte relationship in the Anavilhanas Archipelago, a black water system in the Central Amazon. J. Fish. Biol., 29, 1-11.

Dibble, E. D. and Harrel, S. L. (1997), Largemouth bass diets in two aquatic plant communities. J. Aquat. Plant Manage., 35, 74-78.

Dibble, E. D.; Killgore, K. J. and Dick, G. O. (1996a), Measurement of plant architecture in seven aquatic plants. J. Freshwater Ecol., 11, 311-318.

Dibble, E. D.; Killgore, K. J. and Harrel, S. L. (1996b), Assessment of fish-plant interactions. In: Miranda, E. and DeVries, D. R. (Eds.). Multidimensional approaches to reservoir fisheries management. Lamerican Fisheries Society, Symposium 16, Bethesda, Maryland. pp. 357-372.

Diehl, S. (1988), Foraging efficiency of three freshwater fishes: effects of structural complexity and light. Oikos, 53, 207-214.

Duarte, C. M. (1987), The use of echosounder tracing to estimate the standing crop of submersed plants in lakes. Can. J. Fish. Aquat. Sci., 44, 851-855.

Farmer, M. A. and Adams, M. S. (1991), The nature of scale and the use of hierarchy theory in understanding the ecology of aquatic macrophytes. Aquat. Bot., 41, 253-261.

Ferrer-Montano, O. J. and Dibble, E. D. (2002), Aquatic plant densities and larval fish abundance in vegetated habitats on the Tennessee-Tombigbee waterway system. J. Freshwater Ecol., 17, 455-460.

Floyd, K. B.; Hoyt, R. D. and Pimbrook, S. (1984), Chronology of appearance and habitat partitioning by stream larval fishes. T. Am. Fish. Soc., 113, 217-223.

Gilinsky, E. (1984), The role of fish predation and spatial heterogeneity in determining benthic community structure. Ecology, 4, 455-468.

Gotelli, N. J. and Entsminger, G. L. (2001), EcoSim: Null models software for ecology. Version 7.0. Acquired Intelligence Inc. and Kesey-Bear. Available in: http://homepages.together.net/ gentsmin/ecosim.htm.

Harrel, S. L. and Dibble, E. D. (2001), Foraging efficiency of juvenile bluegill, Lepomismacrochirus, among different vegetated habitats. Environ. Biol. Fish., 62, 441-453.

Henry, R. and Costa, M. L. R. (2003), As macrófitas aquáticas como fator de heterogeneidade: um estudo em três lagoas com diferentes conectividades com o rio Paranapanema. In: Thomaz, S. M. and Bini, L. M. (Eds.). Ecologia e Manejo de Macrófitas Aquáticas. Maringá: Eduem. pp. 189-210.

Jones, J. I.; Hardwick, K. and Eaton, J. W. (1996), Diurnal carbon restrictions on the photosynthesis of dense Elodea nutalli (Planch.)St. John. Hydrobiologia, 340, 11-16.

Johnson, S. L. (1993), Cover choice by bluegills: orientation of underwater structure and light intensity. T. Am. Soc., 122, 148-154. 
Keast, A. (1984), The introduced aquatic macrophyte, Myriophyllum speciatum, as habitat for fish and their invertebrate prey. Can. J. Zool., 62, 1289-1303.

Krebs, C. J. (2001), Ecology. San Francisco: Benjamin Cummings.

Lansac-Tôha, F. M.; Velho, L. F. M. and Bonecker, C. C. (2003), Influência de macrófitas aquáticas sobre a estrutura da comunidade zooplanctônica. In: Thomaz, S. M. and Bini, L. M. (Eds.). Ecologia e Manejo de Macrófitas Aquáticas. Maringá: Eduem. pp. 231-242.

Lillie, R. A. and Budd, J. (1992), Habitat architecture of Myriophyllum L. as an index to habitat quality for fish and macroinvertebrates. J. Freshwater Ecol., 7, 113-125.

Lynch, W. E. and Johnson, D. L. (1989), Influences of interstice size, shade, and predator on the use of artificial structure by bluegills. N. Am. J. Fish. Manage., 9, 219-225.

Maceina, M. J., Shireman, J. V., Laneland, K. A. and Canfield Jr., D. E. (1984), Prediction of submersed plant standing crop by use of a recording fathometer. J. Aquat. Plant Manage., 22, 35-38.

Miranda, L. E., Driscoll, M. P. and Allen, M. S. (2000), Transient physicochemical microhabitats facilitated fish survival in inhospitable aquatic plant stand. Freshwater Biol., 44, 617-628.

Murphy, K. J.; Dickinson, G.; Thomaz, S. M.; Bini, L. M.; Dick, K.; Greaves, K.; Kennedy, M. P.; Livingstone, S.; McFerran, H.; Milne, J. M.; Oldroyd, J. and Wingfield, R. A. (2003), Aquatic plant communities and predictors of diversity in a subtropical river floodplain: the upper Rio Paraná, Brazil. Aquat. Bot., 77, 256-276.
Pelicice, F. M.; Agostinho, A. A. and Thomaz, S. M. (2005), Fish Assemblages Associated With Egeria in a Tropical Reservoir: Investigating the Effects of Plant Density and Diel Period. Acta Oecol., 27, 9-16.

Taniguchi, H.; Nakano, S. and Tokeshi, M. (2003), Influences of habitat complexity on the diversity and abundance of epiphytic invertebrates on plants. Freshwter Biol., 48, 718-728.

Takeda, A. M.; Souza-Franco, G. M.; Melo, S. M. and Monkolski, A. (2003), Invertebrados associados às macrófitas aquáticas da planície de inundação do alto rio Paraná (Brasil). In: Thomaz, S. M. and Bini, L. M. (Eds.). Ecologia e Manejo de Macrófitas Aquáticas. Maringá: Eduem. pp. 243-260.

Vono, V. and Barbosa, F. A. R. (2001), Habitats and littoral zone fish community structure of two natural lakes in southeast Brazil. Hydrobiologia, 61, 371-379.

Weaver, M. J.; Magnuson, J. J. and Clayton, M. K. (1996), Habitat heterogeneity and fish community structure: inferences from north temperate lakes. In: Miranda, L. E. and DeVries, D. R. (Eds.). Multidimensional approaches to reservoir fisheries management. Symposium 16, American Fisheries Society, Bethesda, Maryland. pp. 335-346.

Received: August 10, 2004; Revised: February 22, 2005; Accepted: January 12, 2006. 